\title{
SJP-L-5, a novel small-molecule compound, inhibits HIV-1 infection by blocking viral DNA nuclear entry
}

\author{
Ru Bai ${ }^{1}$, Xing-Jie Zhang ${ }^{3}$, Yan-Li Li ${ }^{1}$, Jing-Ping Liư ${ }^{4}$, Hong-Bin Zhang ${ }^{5}$, Wei-Lie Xiao ${ }^{4}$, Jian-Xin Pu ${ }^{4}$, Han-Dong Sun ${ }^{4}$, \\ Yong-Tang Zheng ${ }^{3^{*}}$ and Li-Xin Liü ${ }^{2^{*}}$
}

\begin{abstract}
Background: Small-molecule compounds that inhibit human immunodeficiency virus type 1 (HIV-1) infection can be used not only as drug candidates, but also as reagents to dissect the life cycle of the virus. Thus, it is desirable to have an arsenal of such compounds that inhibit HIV-1 infection by various mechanisms. Until now, only a few small-molecule compounds that inhibit nuclear entry of viral DNA have been documented.

Results: We identified a novel, small-molecule compound, SJP-L-5, that inhibits HIV-1 infection. SJP-L-5 is a nitrogen-containing, biphenyl compound whose synthesis was based on the dibenzocyclooctadiene lignan gomisin M2, an anti-HIV bioactive compound isolated from Schisandra micrantha A. C. Smith. SJP-L-5 displayed relatively low cytotoxicity (50\% cytoxicity concentrations were greater than $200 \mu \mathrm{g} / \mathrm{ml}$ ) and high antiviral activity against a variety of HIV strains (50 \% effective concentrations $\left(\mathrm{EC}_{50}\right)$ ) of HIV-1 laboratory-adapted strains ranged from $0.16-0.97 \mu \mathrm{g} / \mathrm{ml}$; $\mathrm{EC}_{50} \mathrm{~S}$ of primary isolates ranged from $1.96-5.33 \mu \mathrm{g} / \mathrm{ml}$ ). Analyses of the viral DNA synthesis indicated that SJP-L-5 specifically blocks the entry of the HIV-1 pre-integration complex (PIC) into the nucleus. Further results implicated that SJP-L-5 inhibits the disassembly of HIV-1 particulate capsid in the cytoplasm of the infected cells.
\end{abstract}

Conclusions: SJP-L-5 is a novel small-molecule compound that inhibits HIV-1 nuclear entry by blocking the disassembly of the viral core.

Keywords: HIV-1, Pre-integration complex, Nuclear entry, Capsid, SJP-L-5

\section{Background}

The development of highly active antiretroviral therapy (HAART) in 1996 was a huge breakthrough in the treatment of human immunodeficiency virus type 1 (HIV-1) infections [1]. The combination of a three-drug therapy (cocktails) that target the viral reverse transcriptase and protease effectively reduce the viral loads of patients and prolonged their lives [2]. However, HAART has limitations. It cannot eradicate HIV-1, and there are problems with drug toxicity, as well as the emergence of drugresistant strains [3]. These issues highlight the need to discover and develop new classes of HIV-1 inhibitors.

\footnotetext{
* Correspondence: zhengyt@mail.kiz.ac.cn; liulixin@mail.sysu.edu.cn

${ }^{3}$ Key Laboratory of Animal Models and Human Disease Mechanisms of the

Chinese Academy of Sciences and the Kunming Institute of Zoology of the

Chinese Academy of Sciences, Kunming 650223, P. R. China

${ }^{2}$ Sun Yat-Sen University, Guangzhou 510275, P. R. China

Full list of author information is available at the end of the article
}

The life cycle of HIV-1 contains a number of distinct steps that can be used as targets for therapy. HIV-1 undergoes various steps in the host cell, including receptor binding, fusion, uncoating, reverse transcription, nuclear import, integration, transcription, translation, assembly, release and maturation to generate infective progeny. Theoretically, agents that can interfere with any of the steps of viral replication could be a valued addition to the therapeutic arsenal.

Currently, a variety of compounds have been found that can inhibit HIV-1 replication, including viral fusion inhibitors, reverse transcriptase inhibitors, protease inhibitors, and integrase inhibitors [4-8]. During the early stages of infection, HIV-1 has to transport its PIC into the nucleus for integration of the viral genome into the host DNA. This critical step for HIV-1 has attracted increasing interest as a potential drug target. It is believed that the PIC 
enters the nucleoplasm by passing through nuclear pore complexes (NPCs), which are composed of over 30 different nucleoporins that form stable channels in the nuclear envelope [9]. Many of the viral elements found in association with the PIC have been proposed to be important for HIV-1 nuclear import. The nuclear localization signals (NLSs) present in the viral matrix (MA) and integrase (IN) proteins, as well as various non-canonical karyophilic signals in the viral protein regulatory $(\mathrm{Vpr})$, have been proposed to recruit cellular nuclear transport proteins that facilitate entry of the PIC into the nucleus [9-12]. The triple-stranded DNA flap, a cDNA intermediate of reverse transcription, was suggested to indirectly influence viral nuclear import [13]. Recently, a handful of reports suggested that the viral capsid (CA) protein plays important roles in nuclear import $[14,15]$. Although the nuclear import step presents an important target for anti-viral therapeutic intervention, there is still no approved drug that targets the nuclear import mechanism.

In this study, we identified a new nitrogen-containing biphenyl compound, SJP-L-5, which can effectively inhibit both laboratory-adapted HIV-1 strains and primary isolates infection in C8166 cells and peripheral blood mononuclear cells (PBMCs). The synthesis of this new compound was based on an anti-HIV-1 bioactive dibenzocyclooctadiene lignan, gomisin M2 (SM10), from Schisandra micrantha A. C. Smith. SJP-L-5 displays relatively low cytotoxicity [16]. Further analyses showed that SJP-L-5 effectively and specifically inhibits HIV-1 replication in the pre-integration stage of the viral life cycle. It blocks viral PIC nuclear import by inhibiting viral capsid uncoating, without inhibiting the function of NLS in viral proteins. Unlike other reported capsid disassembly inhibitors, SJP-L-5 does not inhibit viral reverse transcription. Thus, the unique feature of SJP-L-5 makes this new compound not only a promising therapeutic candidate in the future, but also provides a novel tool to understand the post-entry, pre-integration events in HIV-1 infection.

\section{Results}

Cytotoxicity and antiviral activity of SJP-L-5

SJP-L-5 was synthesized based on the anti-HIV-1 bioactive dibenzocyclooctadiene lignan, gomisin M2 (SM10), from S. micrantha A. C. Smith (Fig. 1). To evaluate the toxicity of SJP-L-5 toward different cell lines and primary cells, 3-(4, 5-Dimethyl-2-thiazolyl)-2, 5-diphenyl$2 \mathrm{H}$-tetrazolium bromide (MTT) methods were used. The $50 \%$ cytotoxicity concentrations $\left(\mathrm{CC}_{50} \mathrm{~S}\right)$ for SJP-L-5 in C8166, MT-4, H9/HIV-1 ${ }_{\text {IIIB }}$, and PBMC cells were higher than $200 \mu \mathrm{g} / \mathrm{ml}$ (Fig. 2). To investigate the antiviral activity of SJP-L-5, HIV-1 laboratory-adapted strains (HIV-1IIIB, HIV-1MN, and HIV-1RF) and primary isolates (HIV-1 KM018, HIV-1WAN, and HIV-1TC-2) were used to infect

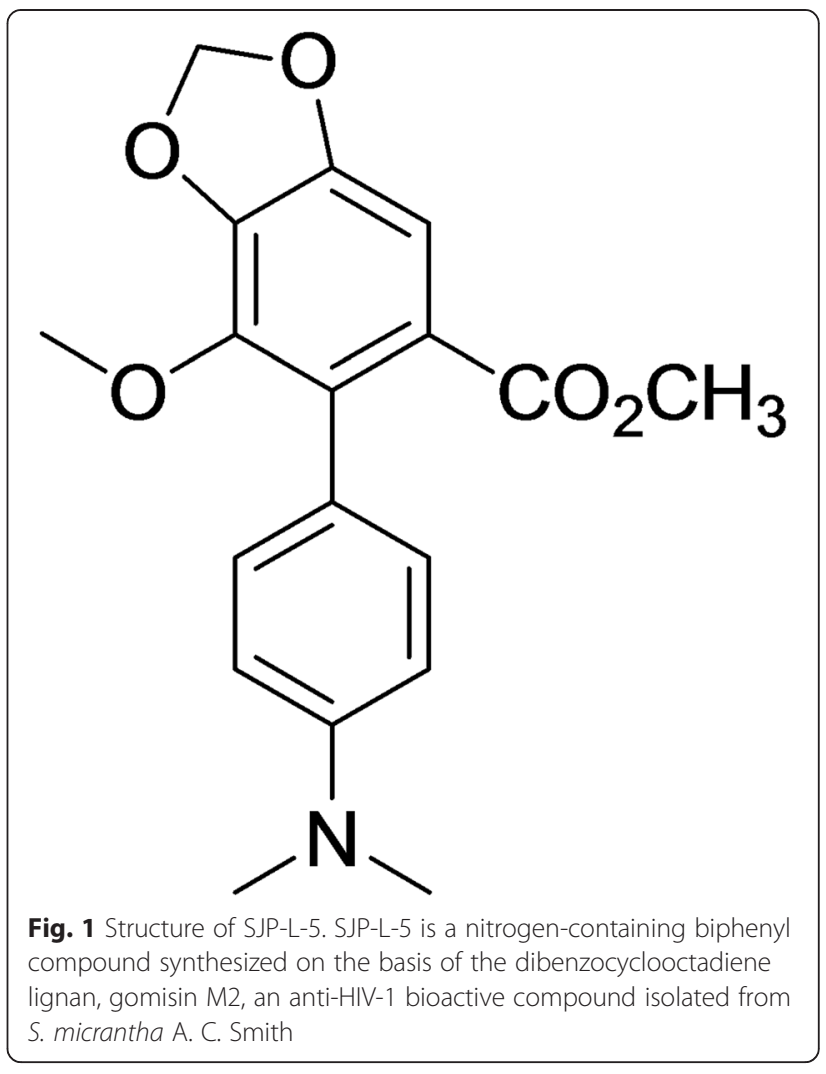

C8166 (Fig. 3a) and PBMC cells (Fig. 3b), respectively. SJP-L-5 was a potent inhibitor of HIV-1 $1_{\mathrm{IIIB}}, \mathrm{HIV}-1_{\mathrm{MN}}$, and $\mathrm{HIV}-1_{\mathrm{RF}}$ (Table 1), and its $\mathrm{EC}_{50}$ values were ranged from 0.16 to $0.97 \mu \mathrm{g} / \mathrm{ml}$. It also inhibited the primary isolates HIV-1 $1_{\mathrm{KM} 018}$, HIV-1 $1_{\mathrm{WAN}}$, and HIV-1 ${ }_{\mathrm{TC}-2}$, which are prevalent in China, with $\mathrm{EC}_{50}$ s ranging from 1.96 to $5.33 \mu \mathrm{g} / \mathrm{ml}$ (Table 1). After the viral inhibition efficiency and cytotoxicity of SJP-L-5 were identified, a pseudotyped virus

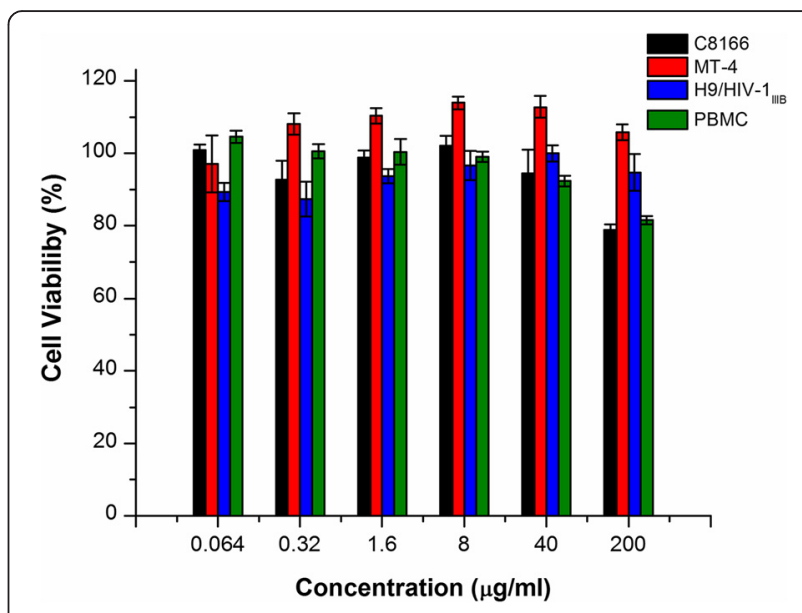

Fig. 2 Cytotoxicity of SJP-L-5 in C8166, MT-4, H9/HIV-1 ${ }_{\| \mathrm{BB}}$ and PBMC cells using the MTT colorimetric method. SJP-L-5 showed low cytotoxicity to all four cell types. The $\mathrm{CC}_{50}$ of these cells was $>200 \mu \mathrm{g} / \mathrm{ml}$, respectively 


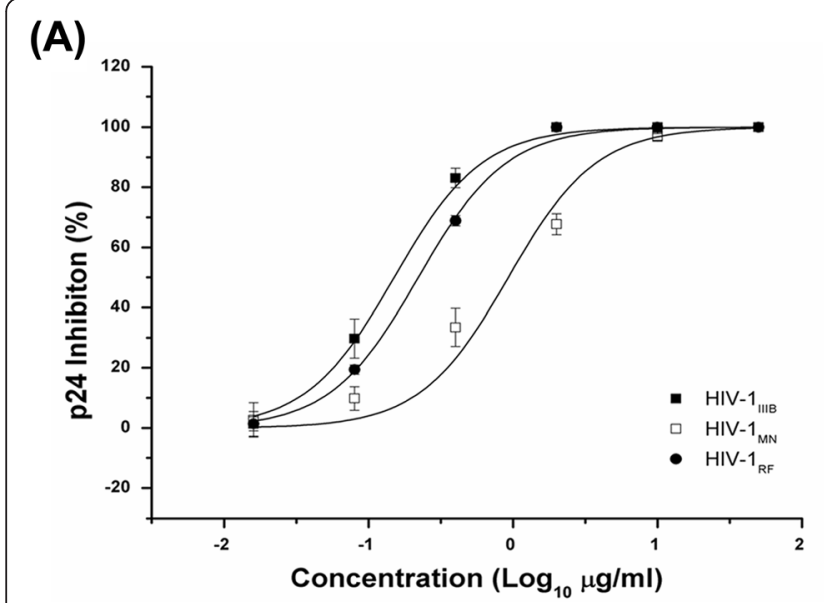

(B)

Fig. 3 Anti-HIV-1 activity of SJP-L-5. a Lab-adapted strains HIV-1 ${ }_{\| I B}$, HIV-1 ${ }_{M N}$, and HIV-1 RF $_{\text {infect C }} 8166$ cells, and they were used to measure the antiviral activity of SJP-L-5. The $\mathrm{EC}_{50} \mathrm{~S}$ of these strains ranged from $0.16-0.97 \mu \mathrm{g} / \mathrm{ml}$. b Clinical isolates HIV-1 ${ }_{\mathrm{KM} 018}, \mathrm{HIV}-1_{\mathrm{TC}-2}$, and HIV-1 WAN $_{\text {are }}$ used to infect PBMC cells and were measured the antiviral activity of SJP-L-5. The $E C_{50} \mathrm{~S}$ of these primary isolates ranged from $1.96-5.33 \mu \mathrm{g} / \mathrm{ml}$

system was used to investigate the molecule's anti-viral mechanism.

\section{SJP-L-5 specifically inhibits HIV-1 infection at the pre-integration stage}

To examine whether the inhibition of infection extends to retroviruses besides HIV-1, we assayed infection by HIV-1 and murine leukemia virus (MLV) in the presence of SJPL-5 $(20 \mu \mathrm{g} / \mathrm{ml}) .293 \mathrm{~T}$ cells were infected with vesicular stomatitis virus (VSV)-G pseudotyped HIV-1-luciferase (Luc) or MLV-Luc viruses. At $48 \mathrm{~h}$ post infection, luciferase activity was measured with a luminometer. As was shown in Fig. 4a, SJP-L-5 specifically inhibited HIV-1 infection. The viral encoded luciferase activity in SJP-L-5 treated cells was reduced to $1.5 \%$ comparing to that in DMSO treatment cells $(P=0.0011, n=3)$, while SJP-L-5 showed no effect on MLV infection. This result demonstrated the selectivity of SJP-L-5's antiviral activity.

Since SJP-L-5 could selectively inhibit VSV-G pseudotyped HIV-1-luciferase virus infection, further experiments were conducted to identify which step of the HIV-1 life cycle was blocked by SJP-L-5. By convention, the complicated HIV-1 life cycle was divided into pre-integration and post-integration stages. The steps from receptor binding to PIC nuclear import were referred to as the preintegration stage, and the rest of the replication steps of HIV-1 were considered to be the post-integration stage. Using assays developed by Guangxia Gao's group [17], we infected $293 \mathrm{~T}$ cells with VSV-G pseudotyped HIV-1green fluorescent protein (GFP) in the presence of different concentrations of SJP-L-5 $(0,1.25,5$, or $20 \mu \mathrm{g} / \mathrm{ml})$, with DMSO as a negative control and azidothymidine (AZT) $(10 \mu \mathrm{M})$ as a positive control. The results were observed by a fluorescence microscope (Fig. 4b), which showed that SJP-L-5 inhibited the infection of VSV-G pseudotyped HIV-1-GFP in a dose-dependent manner, consistent with the results shown in Fig. 4a. To determine whether SJP-L-5 could block the post-integration stage of the viral life cycle, a proviral luciferase reporter DNA genome bypassing the pre-integration stage of infection was transfected into $293 \mathrm{~T}$ cells. The results showed that the expression of the reporter from the proviral DNA was not

Table 1 Anti-HIV-1 activity of SJP-L-5

\begin{tabular}{|c|c|c|c|c|}
\hline \multirow[t]{2}{*}{ Strains $^{a}$} & \multirow[t]{2}{*}{ Subtypes } & \multirow[t]{2}{*}{ Tropisms } & \multicolumn{2}{|c|}{$\mathrm{EC}_{50}(\text { Mean } \pm \mathrm{SD})^{b}$} \\
\hline & & & $\overline{S J P}-\mathrm{L}-5(\mu \mathrm{g} / \mathrm{ml})$ & $A Z T^{c}(\mathrm{ng} / \mathrm{ml})$ \\
\hline HIV-1 ${ }_{\text {IIIB }}$ & $B$ & $x 4$ & $0.16 \pm 0.03$ & $29.7 \pm 9.7$ \\
\hline $\mathrm{HIV}-1_{\mathrm{MN}}$ & B & $x 4$ & $0.97 \pm 0.13$ & $0.9 \pm 0.1$ \\
\hline$H I V-1_{R F}$ & B & $x 4$ & $0.18 \pm 0.04$ & $80.0 \pm 25.5$ \\
\hline HIV-1 KM018 & CRF07_BC & R5 & $2.32 \pm 0.41$ & $37.7 \pm 15.1$ \\
\hline $\mathrm{HIV}-1_{\mathrm{TC}-2}$ & CRF01_AE & $x 4$ & $1.96 \pm 0.22$ & $5.0 \pm 1.6$ \\
\hline HIV-1 WAN & CRF07_BC/CRF01_AE & $x_{4}$ & $5.33 \pm 0.85$ & $4.4 \pm 1.5$ \\
\hline
\end{tabular}

${ }^{a_{\mathrm{HIV}}-1_{\text {IIIB }}, \mathrm{HIV}-1_{\mathrm{MN}} \text { and HIV-1 }} 1_{\mathrm{RF}}$ are lab-adapted strains that infect C8166 cells, and they were used to measure the antiviral activity of SJP-L-5; HIV-1 ${ }_{\mathrm{KM} 018}$, HIV-1 ${ }_{\mathrm{TC}-2}$, and HIV-1 WAN are clinical isolates that infect PBMC cells, and they were also used to measure the antiviral activity of SJP-L-5

${ }^{b} \mathrm{n} \geq 3$

${ }^{c} \mathrm{AZT}$, azidothymidine 


\section{(A)}

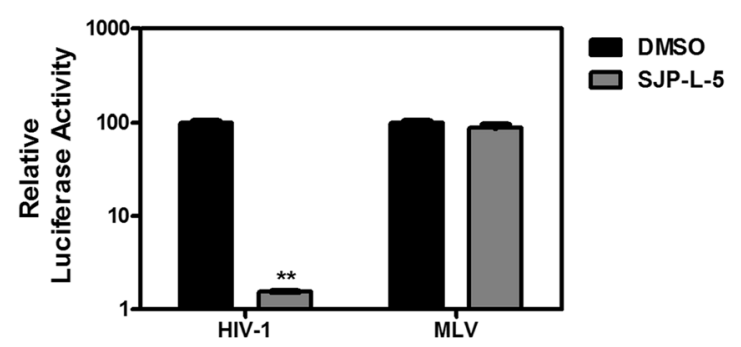

(B)
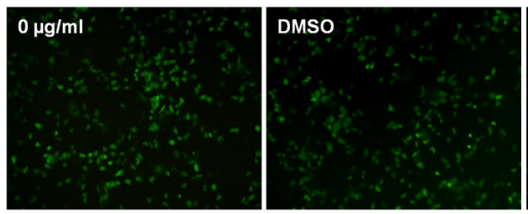

AZT
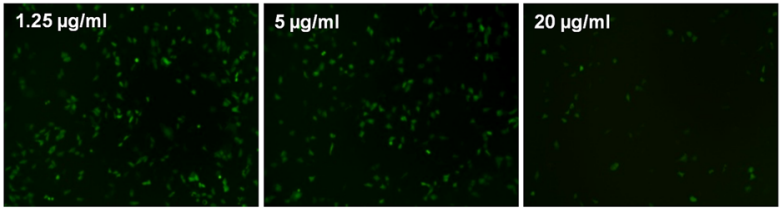

(C)

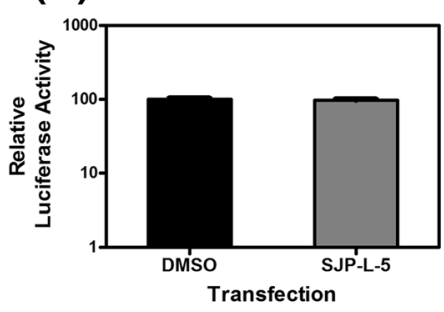

(D)

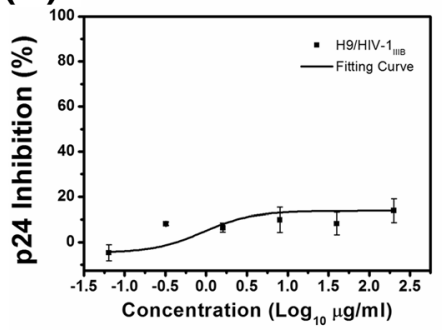

Fig. 4 SJP-L-5 specifically inhibits HIV-1 at the pre-integration stage. a 293 T cells were infected with VSV-G pseudotyped HIV-1-Luc or MLV-Luc in the presence of SJP-L-5 (5 $\mathrm{gg} / \mathrm{ml}$, Gray) or DMSO (Black) as a negative control. The antiretroviral activity was evaluated by testing the activity of the luciferase reporter gene at $48 \mathrm{~h}$ post infection. Error bars indicate standard deviations of triplicate values. Statistical significance was analyzed by the Student's $t$ test. ${ }^{* *} P<0.01$ versus the negative control. $\mathbf{b} 293$ T cells were infected with VSV-G pseudotyped HIV-1-GFP, in the presence of SJP-L-5 (0, 1.25, 5, or $20 \mu \mathrm{g} / \mathrm{ml})$, or DMSO as a negative control; AZT (10 $\mu \mathrm{M})$ was used as a positive control. $24 \mathrm{~h}$ after infection, infectivity was analyzed with a fluorescence microscope. c 293 T cells were transfected with 0.1 Mg of pNL4-3luc in the presence of SJP-L-5 (5 $\mu \mathrm{g} / \mathrm{ml}$, (Gray)) or DMSO (Black) as

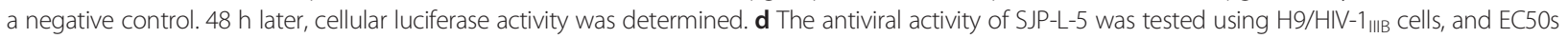
were greater than $200 \mu \mathrm{g} / \mathrm{ml}$. The inhibition was calculated as the p24 levels in control cells divided by that in SJP-L-5 treated cells

affected by SJP-L-5 treatment compared to the DMSO treated control $(n=3)$ (Fig. $4 \mathrm{c}$ ), suggesting that SJP-L-5 did not affect the post-integration stage of the HIV-1 life cycle, which includes viral genome integration, transcription, transport out of the nucleus, and viral protein translation. To confirm that SJP-L-5 did not affect the viral post-integration steps including HIV-1 transcription and translation, we also investigated the antiviral activity of SJP-L-5 in the chronically infected H9/HIV-1IIIB cell line which stably expresses HIV-1 IIв proviral DNA. The $\mathrm{EC}_{50} \mathrm{~S}$ of SJP-L-5 were greater than $200 \mu \mathrm{g} / \mathrm{ml}$. Furthermore, there was no significant difference in the levels of p24 (CA) between the DMSO treated control and the SJPL-5 treated group $(n=3)$ (Fig. $4 \mathrm{~d})$. Taken together, these results showed that SJP-L-5 blocked HIV-1 infection at stages of pre-integration.

\section{SJP-L-5 blocks the nuclear entry of the pre-integration} step in the HIV-1 life cycle

To further explore the exact step at which SJP-L-5 blocks the pre-integration stage of the HIV-1 life cycle, $293 \mathrm{~T}$ cells were infected with VSV-G pseudotyped HIV-1-GFP virus, and synthesis of the viral DNA was examined by real-time PCR. Formation of a minus-strand strong-stop DNA (-sssDNA) is the first step of reverse transcription and the full-length DNA (flDNA) synthesis represents the last step of reverse transcription [18] (Fig. 5a). We detected both -sssDNA and flDNA levels in HIV-1 infected 293 T cells, with or without the treatment of SJP-L-5. SJPL-5 treatment had little effect on the levels of -sssDNA (Fig. 5b) and flDNA (Fig. 5c), while the RT inhibitor AZT effectively reduced the flDNA levels, implicating that SJPL-5 does not inhibit reverse transcription. To test whether 


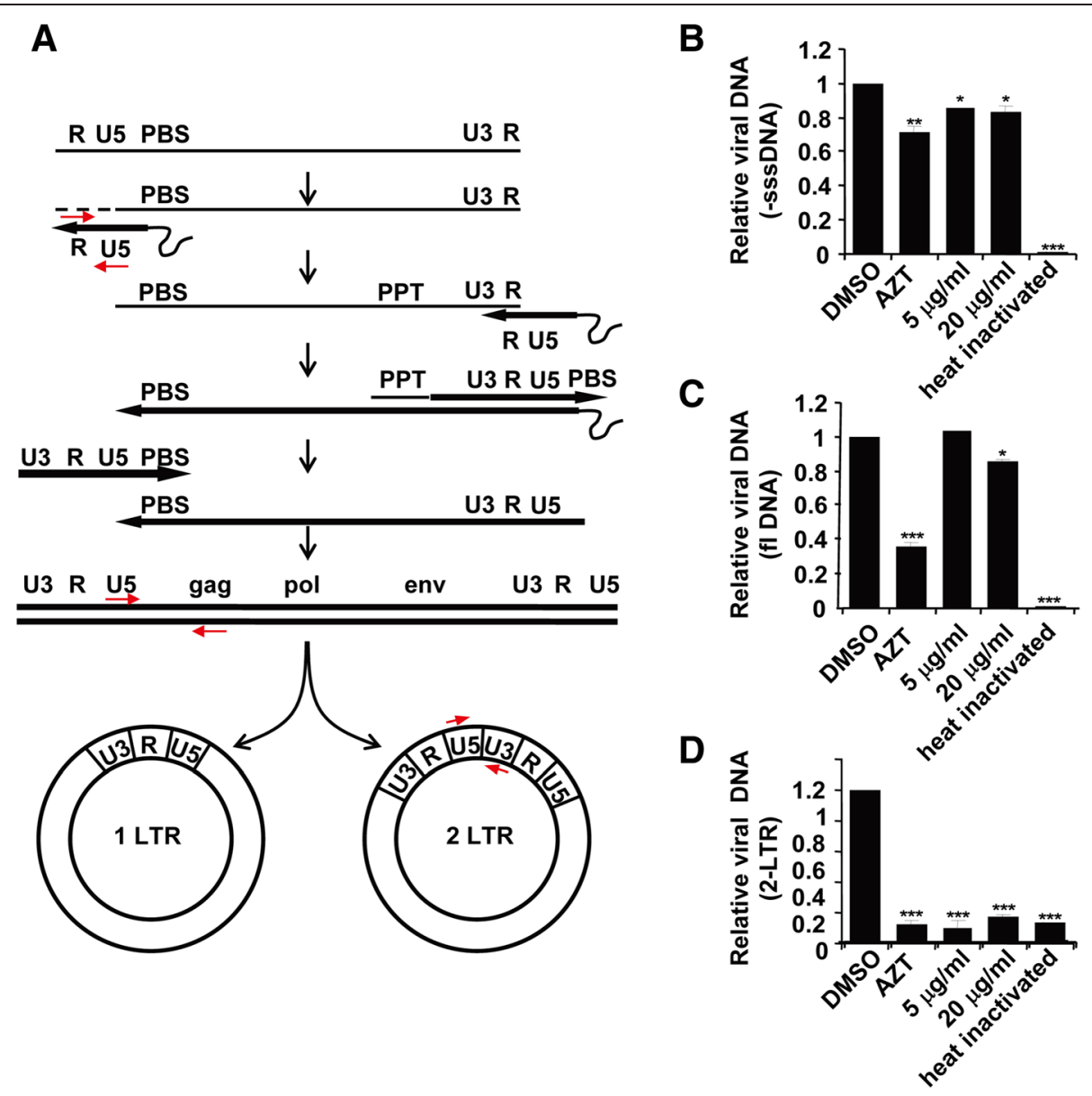

Fig. 5 Real-time PCR analysis of the formation of HIV-1 DNAs. a Schematic representation of the reverse transcription and integration of HIV-1 genome. The primers used to amplify the viral DNAs were indicated. b-d. Real-time PCR analysis of HIV-1 DNA in 293 T cells. 293 T cells were infected with VSV-G pseudotyped HIV-1-GFP in the presence of DMSO (control) or SJP-L-5 at indicated concentrations. AZT (10 $\mu$ M) was used as a positive control. At $24 \mathrm{~h}$ post infection, low-molecular-weight DNA, including the viral DNA, was isolated. The viral -sssDNA (b), flDNA (c), and 2-LTR circular DNA (d) levels were measured by real-time PCR. Error bars indicate standard deviations of triplicate values. Statistical significance was analyzed by the Student's $t$ test. ${ }^{*} P<0.05,{ }^{* *} P<0.01$ and ${ }^{* * *} P<0.001$ versus the negative control

SJP-L-5 inhibits virus nuclear entry, the 2-long terminal repeat circles (2-LTR) were analyzed. 2-LTR circles are the dead-end byproducts of the viral life cycle, and a conventional marker of nuclear entry [19-22] (Fig. 5a). Data showed that SJP-L-5 treatment significantly reduced the level of 2-LTR circles (Fig. 5d). The reduction in the level of 2-LTR circles suggests that SJP-L-5 interferes with the import of the PIC into the nucleus.

\section{SJP-L-5 does not affect the subcellular localization of HIV-1 IN, MA or Vpr protein}

We next analyzed the mechanism by which SJP-L-5 blocks the nuclear entry of the PIC. Currently, the molecular mechanism that regulates the delivery of the HIV-1 PIC into the nucleus is not entirely clear. Three karyophilic viral proteins, including HIV-1IN [23-25], MA [26-31], and $\mathrm{Vpr}$ [32], have been reported to contain one or two NLSs that can promote the active nuclear import of the
PIC. HIV-1 MA contains two subcellular localization signals: a myristoylated $\mathrm{N}$-terminus governs particle assembly at the plasma membrane and an NLS that facilitates the import of the PIC into the nucleus of non-dividing cells [26-28]. These two crucial functions act at different stages of the HIV-1 life cycle. Myristoylation occurs at the Nterminus of MA and prevents the NLS-mediated transport of MA to the nucleus [26-28]. To investigate only the karyophilic function of MA in the nuclear import of the PIC, GFP was in-frame fused with the N-terminus of MA to block the myristoylation (GFP-MA). GFP was also inframe fused with the C-terminus of MA so that the myristoylation was not affected (myrMA-GFP). We also constructed plasmids with GFP fused to the N-terminus of IN and Vpr (GFP-IN and GFP-Vpr), the primers used in the plasmids construction were listed in Additional file 1: Table S1. 293 T cells were transiently transfected with the corresponding expression plasmids. As shown in 
Additional file 2: Figure S1 (A), myrMA-GFP localized in the cytoplasm and associated with the plasma membrane, but was excluded from the nucleus, while GFPMA localized in the nucleus. GFP-IN and GFP-Vpr also localized in the nucleus [see Additional file 2: Figure S1 (A)]. GFP alone localized in both the nucleus and the cytoplasm. $\mathrm{GFP}_{2}$-NLS, which contains an NLS sequence, localized in the nucleus. These results suggest that the GFP fusion proteins localized properly. Then, SJP-L-5 $(5 \mu \mathrm{g} / \mathrm{ml})$ was added to the cells to determine whether SJP-L-5 blocked the nuclear import of the PIC by interacting with these three proteins. The results showed that SJP-L-5 did not alter the subcellular distribution of the three viral proteins. A higher concentration of SJP-L-5 $(20 \mu \mathrm{g} / \mathrm{ml})$ also failed to alter the proteins' localization [see Additional file 2: Figure S1 (B-D)]. These observations suggest that SJP-L-5 does not affect the transport of these three karyophilic viral proteins and that SJP-L-5 blocks the nuclear import of the PIC through mechanisms other than NLS-mediated nuclear transport.

\section{SJP-L-5 does not target the DNA flap}

Given the important roles of DNA flap played in PIC nuclear import [13, 76], we tested whether SJP-L-5 activity targets this element. We used CMV $\Delta$ R8.2-Luc (pCMV $\Delta$ R8.2 encoding Gag and Gag-Pol, together with a genomic RNA encoding plasmid pHR'-Luc which lacks the flap) virus. 293 T cells were infected with VSV-G pseudotyped NL4-3Luc which contains the flap sequence or CMV $\Delta$ R8.2-Luc in the presence of SJP-L-5. At $48 \mathrm{~h}$ post infection, luciferase activity was measured with a luminometer. Treatment of SJP-L-5 resulted in significant inhibitions in both NL4-3luc and CMVAR8.2-luc infection, comparing to the DMSO treated controls [see Additional file 3: Figure S2]. This result suggests that the DNA flap-mediated nuclear import was not a dominant target for SJP-L-5. The specific inhibition of HIV-1 infection, along with the results described above, led us to test whether SJP-L-5 plays a role in uncoating the viral capsid from the PIC.

\section{SJP-L-5 inhibits HIV-1 capsid disassembly}

MLV can only infect mitosing cells, in which the nuclear envelope is dissolved during cell division. MLV keeps its CA intact when its DNA is transported to the nucleus [33]. In contrast, HIV-1 infects post-mitotic cell types, and accordingly, its viral CA shell has to be dissembled during nuclear entry. Various studies have reported the importance of HIV-1 CA in the infection of non-dividing cells [34-37].

A fate-of-capsid assay was used to investigate whether SJP-L-5 could prevent the viral CA proteins from dissociating from PICs. This method was developed by Joseph Sodroski's lab and was successfully used to analyze CA disassembly by evaluating the levels of particulate and soluble CA in the cytosol of infected cells [37-39]. At different time points post infection, cell lysates were layered onto a $50 \%(\mathrm{w} / \mathrm{v})$ sucrose cushion and centrifuged. The samples were collected and analyzed by Western blotting. As was shown in Fig. 6, the levels of pelleted CA in the cells treated with SJP-L-5 were higher than those in the control cells at all time points. Accordingly, the amount of soluble CA in the treated cell cytosol was lower than that in the cytosol of control cells. These data showed that SJP-L-5 inhibited viral DNA nuclear import by blocking CA disassembly.

To further verify whether SJP-L-5 could inhibit HIV-1 capsid uncoating, a transmission electron microscopy (TEM) assay was used to observe the uncoated viral core directly. Based on the results of fate-of-capsid assay, two time points ( $4 \mathrm{~h}$ and $8 \mathrm{~h}$ post infection) were selected for the TEM assay. In contrast to control cells, there were more capsid proteins around the nucleus in the presence of SJP-L-5 $(20 \mu \mathrm{g} / \mathrm{ml})$ (Fig. 7). The TEM results are consistent with those from the biochemical assay (Fig. 6). Thus, it was demonstrated that SJP-L-5 inhibits HIV-1 replication by inhibiting viral capsid dissociation from the PIC, thereby preventing nuclear entry.

\section{Discussion}

In this study, we identified a novel, small molecule, SJPL-5, which could effectively and efficiently inhibit the replication of both laboratory-adapted strains (HIV-1 $1_{\text {IIIB }}$, $\mathrm{HIV}-1_{\mathrm{MN}}$, and $\mathrm{HIV}-1_{\mathrm{RF}}$ ) and primary isolates (HIV$1_{\mathrm{KM} 018}, \mathrm{HIV}-1_{\mathrm{WAN}}$, and HIV-1 ${ }_{\mathrm{TC}-2}$ ) in C8166 and PBMC cells. Furthermore, we analyzed the stage of the viral life cycle that was blocked by SJP-L-5. The results from the step-by-step assays showed that SJP-L-5 can selectively inhibit HIV-1 replication by blocking the nuclear import of PICs (Figs. 4 and 5). Nuclear import of the HIV-1 PIC is a critical step in retrovirus replication. It is believed that various viral elements and host factors are involved in nuclear transport through the NPC. Three main viral factors affect the nuclear import of the PICs: NLS, the DNA flap, and the CA. Three viral proteins, IN, MA, and Vpr, have been reported to contain a NLS(s) and promote the nuclear import of PICs. In this study, we demonstrate that SJP-L-5 has no effect on the NLSmediated nuclear import of the three proteins at 5 and $20 \mu \mathrm{g} / \mathrm{ml}$ concentrations [see Additional file 2: Figure S1 (B-D)], neither does it target the DNA flap (Additional file 3: Figure S2). Therefore, we focused on the last main factor, the CA.

Historically, the retroviruses MLV and HIV-1 were used as model systems to study retroviral nuclear import. MLV PIC contains a large amount of the CA protein [40, 41], while the CA protein is not strongly associated with the PIC of HIV-1 [42-45]. A major difference between them is their abilities to successfully infect non-dividing cells. The 


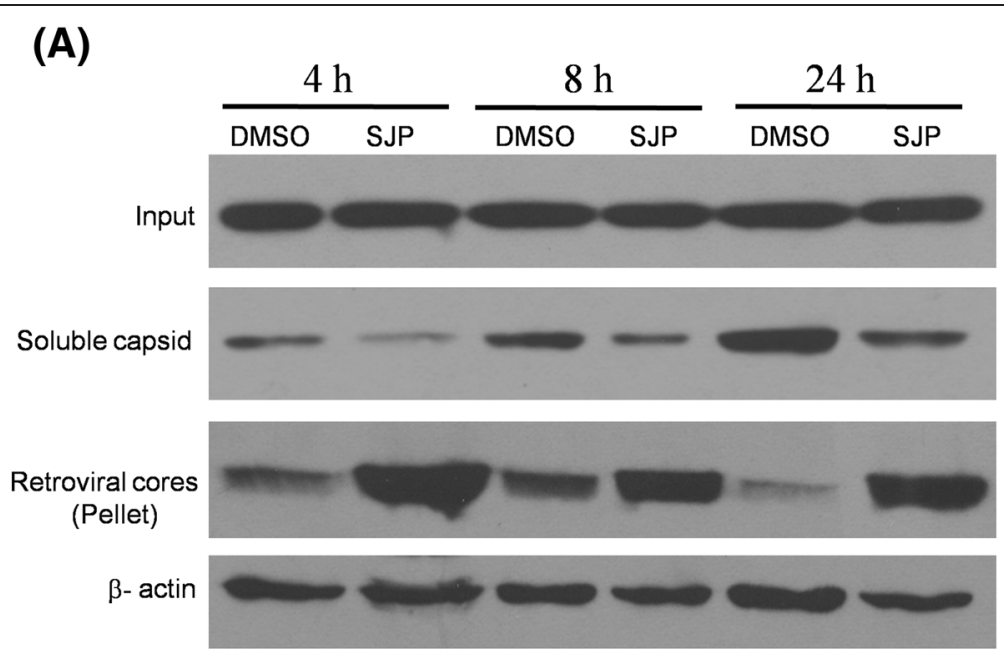

(B)

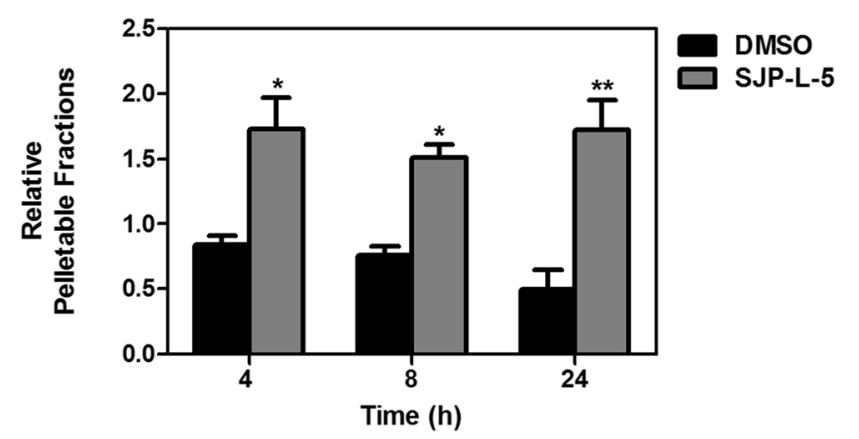

Fig. 6 Effect of SJP-L-5 on the fate of the HIV-1 capsid in infected cells. a 293 T cells were infected with VSV-G pseudotyped HIV-1-GFP for 4 h in the presence of SJP-L-5 at a final concentration of $20 \mu \mathrm{g} / \mathrm{ml}$, or DMSO as a negative control. At different time points post infection, the cells were collected and analyzed using the fate-of-capsid assay, as described in the Methods. The total input, soluble capsid, and pellet fractions were Western blotted using a monoclonal antibody directed against the HIV-1 p24 capsid protein. $\beta$-actin was used as pellet fraction control. b The quantification of the pelleted fraction relative to the input was calculated. Error bars indicate standard deviation in triplicate values. Statistical significance was analyzed by $t$ test. ${ }^{*} P<0.05$ and ${ }^{*} P<0.01$ versus the no drug control. SJP: SJP-L-5

transport of the MLV genome into the nucleus requires the dissolution of the nuclear envelope, although the viral CA does not need to be disassembled; thus, cellular infection by MLV is highly dependent on the state of the cell cycle [33]. In contrast, HIV-1 infects post-mitotic cell types, and the viral CA, accordingly, has to be dissembled before its genome is transported into the host nucleus through an intact nuclear membrane. Various studies had reported the importance of the HIV-1 CA in infections of non-dividing cells [34-37]. Masahiro Yamashita and Michael Emerman reported that the CA was the major determinant of infection in growth-arrested cells. They reported that HIV-1 containing the MLV CA lost the ability to infect nondividing cells, and that mutations in the HIV-1 CA could specifically reduce the infectivity of HIV-1 in non-dividing cells $[36,37]$. Thus, we surmised that SJP-L-5 specifically targets HIV-1 CA disassembly pattern. Using a fate-ofcapsid assay and TEM assays, we observed a reduction in soluble CA and elevated levels of particulate CAs in response to SJP-L-5 treatment (Figs. 6 and 7). Therefore, we obtained consistent results showing that SJP-L-5 blocks the import of the HIV-1 genome into the nucleus by inhibiting capsid disassembly. This result shows that the viral CA protein plays an important role in nuclear import. Yet, the full composition of the viral PIC is not known, and the composition of the PIC varies between different retroviruses. It is clear that differences in PIC composition, including the CA protein, contribute to the different behaviors of viruses in host cells.

Few other inhibitors targeting HIV-1 PIC nuclear entry have been previously described. BI- 1 and BI-2, whose effects are similar to those of SJP-L-5, were reported to decrease the accumulation of 2-LTR circles, without affecting HIV-1 reverse transcription [46]. BI-2 resistant selection studies showed that substitution mutations at positions A105T and $\mathrm{T} 107 \mathrm{~N}$ in the CA protein are the most prevalent mutations, and these two mutation sites surrounded a conserved pocket (site 2), which was formed by alpha helices 3, 4, and 5 in the N-terminal domain of HIV-1 CA. BI1 was shown to bind in this pocket by isothermal titration 


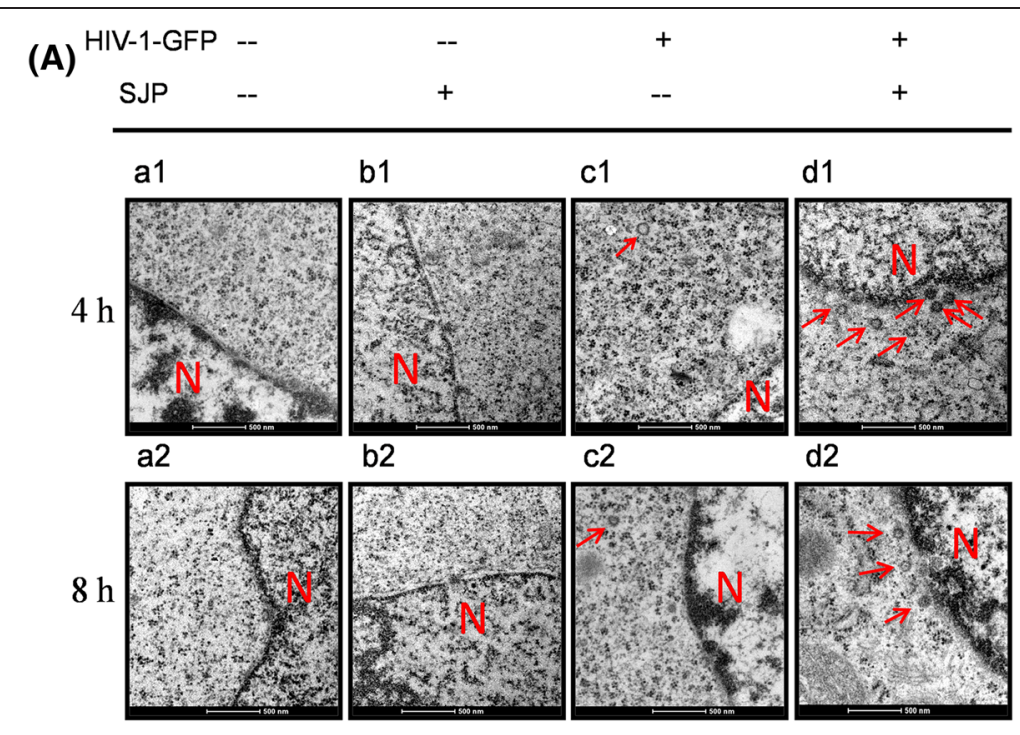

(B)

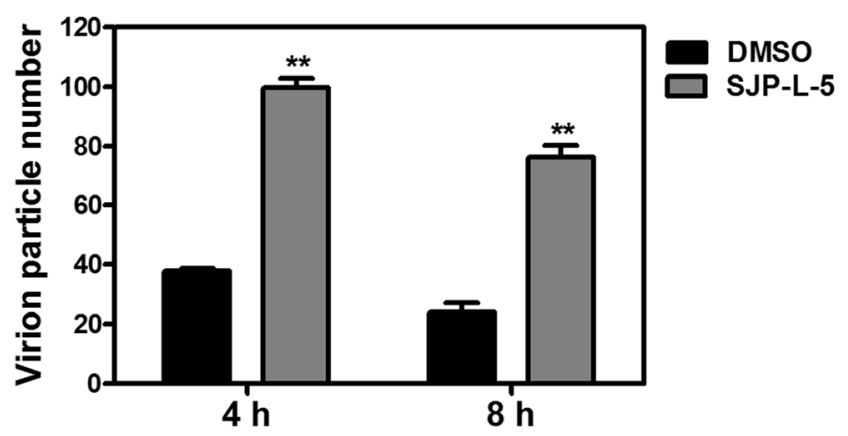

Fig. 7 Electron micrographs of SJP-L-5-treated 293 T cells. a Electron micrographs of the ultrastructure of SJP-L-5-treated cells that were infected with VSV-G pseudotyped HIV-1-GFP. $a_{1}$, $a_{2}$ : blank control. $b_{1}, b_{2}$ : no HIV-1 control (293 T cells were only treated with SJP-L-5). $c_{1}, c_{2}$ : DMSO was used as a negative control (293 T cells were infected by HIV-1 in the absence of SJP-L-5). $d_{1}, d_{2}: 293$ T cells were infected by HIV-1 in the presence of SJP-L-5 $(20 \mathrm{\mu g} / \mathrm{ml})$. N: nucleus. Arrows indicate HIV-1 particles. Scale bars: $500 \mathrm{~nm}$. b Quantification of total HIV-1 particles in 20 fields in the DMSO and SJP-L-5 groups. Error bars indicate standard deviations of triplicate values. Statistical significance was analyzed by the Student's $t$ test. ${ }^{* *} P<0.01$ versus the negative control

calorimetry (ITC), NMR, and X-ray crystallographic analyses [46]. The results of an in vitro stabilization assay showed that BI accelerated the assembly of HIV-1 CA-NC tubes and prevented the dissociation of preassembled CA$\mathrm{NC}$ tubes. Very interestingly, another reported Pfizer inhibitor, PF74, harbors the same binding site in the $C_{N T D}$ site 2 pocket as the BI compounds have [47]. Recent research suggests that BI-2 and PF74 cannot inhibit the ability of an HIV-1 capsid-dependent nuclear import inhibitor $\mathrm{MxB}$ to bind in vitro assembled HIV-1 CA-NC complexes, but block the binding of an HIV-1 capsid-associating protein CPSF6 because PF74, BI-2, and CPSF6 bind to similar regions on the HIV-1 CA [48-50]. PF74 uses a similar mechanism to the one used by BI-2 to block HIV-1, but it inhibits reverse transcription $[47,51]$. Together with our study, more and more evidence indicates the importance of CA in HIV-1 PIC nuclear import.
The well-known restriction factor TRIM $5 \alpha$ family proteins [52-55] also inhibit HIV-1 replication by interacting with the viral CA protein. Two inhibition mechanisms have been identified: one is a proteasome-dependent process, while the other is proteasome-independent. In the proteasome-dependent process, TRIM $5 \alpha$ recognizes specific retroviral CA cores and accelerates the uncoating of incoming viral capsid, this restricts HIV-1 reverse transcription, decreases the production of sssDNA, and prevents HIV-1 replication in infected cells. Some experiments [56-59] have shown that proteasome inhibitors could uncouple with TRIM5 $\alpha$ restriction of HIV-1 reverse transcription in rhesus macaques, but the resultant HIV-1 cDNA could still not enter the nucleus. Kutluay et al. [60] showed that proteasome inhibition restored large sub-viral complexes containing CA, and Campbell et al. [61] found that proteasome inhibition leads to 
the accumulation of fluorescently labeled HIV-1 virions in the cytoplasm of restricted cells, which was the same phenomenon as we observed with SJP-L-5 (Figs. 6 and 7).

Also, a number of cell host proteins have been reported to be involved in the CA uncoating process and PIC nuclear entry. For example, CPSF6 could bind CA and stabilize viral cores [50, 62, 63]; Nup358/RanBP2 aids HIV1 core to dock at NPC [64, 65]; Nup153 binds CA and participates to both HIV-1 translocation and integration steps [66]; CypA could destabilize the capsid shell during viral entry and uncoating step [67], or be a chaperon facilitating correct capsid condensation during viral maturation $[68,69]$. Some studies showed that abrogation of CA binding with CypA, either through CypA depletion or competition with the small molecule cyclosporine, could rescue viruses from the Nup153 and Nup358 depletion cells [70]. The roles of these host factors will give us a clue to find the exact target site of SJP-L-5.

Further studies, including the selection of SJP-L-5-resistant variants, will be needed to explore the exact mechanism of SJP-L-5's blockage of HIV-1 infection, as well as to shed light on the complicated HIV-1 uncoating process.

\section{Conclusion}

In this work, we identified a new nitrogen-containing biphenyl compound, SJP-L-5 that specifically blocks HIV1 PIC import into the nuclei of infected cells. SJP-L-5 inhibited the disassembly of the HIV-1 capsid in the cytoplasm. This novel compound could be used as a potential drug candidate for anti-HIV-1 therapy.

\section{Methods}

\section{Reagents and chemicals}

SJP-L-5 was provided by Professor Handong Sun (Kunming Institute of Botany, Chinese Academy of Sciences). DMSO, AZT, MTT, sodium dodecyl sulfate (SDS), N, Ndimethylformamide (DMF), phytohemagglutinin (PHA), and interleukin-2 (IL-2), were purchased from SigmaAldrich (St. Louis, MO, USA).

\section{Cells and viruses}

C8166, MT-4, and H9 cells were kindly provided by the AIDS Reagent Project, the UK Medical Research Council (MRC). Laboratory-adapted strains, including $\mathrm{HIV}-1_{\mathrm{IIIB}}$, HIV $-1_{\mathrm{MN}}$, and HIV- $1_{\mathrm{RF}}$ were obtained from the NIH AIDS Research and Reference Reagent Program (Bethesda, MD, USA). Clinically isolated HIV-1 strains, including HIV$1_{\mathrm{KM} 018}, \mathrm{HIV}-1_{\mathrm{TC}-2}$, and HIV-1 $1_{\mathrm{WAN}}$ were isolated from local AIDS patients in Yunnan, China, prior to antiviral drug treatment (Ethical Approval Number: SWYX-2009018). PBMCs were isolated by the Ficoll-Hypaque method from whole blood collected from healthy donors (Ethical
Approval Number: SWYX-2009019). Ethical approval was given by the Biomedical Ethics Committee of Kunming Institute of Zoology of the Chinese Academy of Sciences with the following reference number: SWYX-2010018 and SWYX-2010019. Informed written consent was given by the patients and donors before sampling. $293 \mathrm{~T}$ cells used in this study were all maintained in Dulbecco's Modified Eagle's Medium (DMEM) supplemented with $10 \%$ fetal bovine serum (FBS) (Gibco, Grand Island, NY, USA) at $37{ }^{\circ} \mathrm{C}$ in a $5 \% \mathrm{CO}_{2}$-humidified atmosphere. $\mathrm{C} 8166, \mathrm{MT}-4$, and H9/HIV-1 $1_{\text {IIIB }}$ suspension cell lines were maintained in RPMI-1640 medium containing $10 \% \mathrm{FBS}, 100 \mathrm{U} / \mathrm{ml}$ of penicillin G, and $100 \mu \mathrm{g} / \mathrm{ml}$ of streptomycin. PBMCs were stimulated with $5 \mu \mathrm{g} / \mathrm{ml}$ of PHA and maintained with 50 $\mathrm{U} / \mathrm{ml} \mathrm{IL-2}$ and $10 \%$ FBS in RPMI-1640 medium for three days prior to HIV-1 infection. HIV-1 $1_{\text {IIIB }}, \mathrm{HIV}-1_{\mathrm{MN}}$, and HIV- $1_{\mathrm{RF}}$ were propagated in C8166 cells; HIV-1 primary isolates-HIV-1 $1_{\mathrm{KM} 018}, \mathrm{HIV}-1_{\mathrm{WAN}}$, and $\mathrm{HIV}-1_{\mathrm{TC}-2}$ were propagated in PBMCs.

\section{Cytotoxicity}

The cell viability of SJP-L-5 was determined by the MTT method as previously described [71]. Briefly, C8166 cells were diluted in fresh medium to a final concentration of $4 \times 10^{5} / \mathrm{ml}$ and added to a 96-well plate at $100 \mu \mathrm{l} /$ well, and then a series of concentrations of SJP-L-5 were added to each well $(100 \mu \mathrm{l})$. After 3 days of incubation at $37{ }^{\circ} \mathrm{C}, 5 \%$ $\mathrm{CO}_{2}$, the cell viability was determined using MTT; for PBMCs, $5 \times 10^{5}$ cells were added to each well and the plates were incubated for 7 days. The percentage of cell viability was compared to that of the DMSO solvent control. Afterward, the $\mathrm{CC}_{50}$ was calculated by sigmoidal fit using Origin Pro 7.5 software based on the cell viability in the presence and absence of the compound tested. AZT was used as a reference compound. The data presented are representative of three independent experiments.

\section{Antiviral activity}

Antiviral activity was assessed by ELISA as previously described [72]. C8166 cells were infected by HIV-1 $1_{\text {IIIB }}$, $\mathrm{HIV}-1_{\mathrm{MN}}$, or $\mathrm{HIV}-1_{\mathrm{RF}}$ at a multiplicity of infection (MOI) of 0.03 in the presence of different serial concentration of SJP-L-5 as described previously [73]. After a $2 \mathrm{~h}$ infection at $37^{\circ} \mathrm{C}$ in a $5 \% \mathrm{CO}_{2}$ atmosphere, HIV1-infected $\mathrm{C} 8166$ cells were washed three times with phosphate-buffered saline (PBS) to remove free viruses. Next, the infected cells were resuspended in RPMI1640 and seeded into a 96-well plate $\left(4 \times 10^{4}\right.$ in $100 \mu \mathrm{l}$ of RPMI-1640 per well) with $100 \mu \mathrm{l}$ of gradient concentrations of SJP-L-5. AZT was used as a reference compound. On day 3 post infection, p24 levels were measured by an in-house ELISA, and the $\mathrm{EC}_{50}$ was calculated by sigmoidal fit using Origin Pro 7.5 software. 
For PBMCs, cells were infected with HIV-1 $1_{\mathrm{KM} 018}$, HIV$1_{\mathrm{WAN}}$, and HIV-1 $1_{\mathrm{TC}-2}$ at low MOIs $(0.06-0.1)$ for $2 \mathrm{~h}$. Infected PBMCs were then washed three times with PBS, after which $100 \mu \mathrm{l}$ of $5 \times 10^{5}$ infected cells were seeded into each well of a 96-well plate in the presence of a gradient of different concentrations of SJP-L-5. On day 7 post infection, p24 antigen levels were measured by ELISA, and the $\mathrm{EC}_{50}$ was calculated as described above. The data presented are representative of three independent experiments.

\section{Generation of VSV-G pseudotyped viruses}

pMD.G, pCMV $\Delta$ R8.2, pTRIP-GFP, pNL4-3-Luc, pCMVVSV-G, pHIT60, and pMA-Luc plasmids were provided by Professor Guangxia Gao (Institute of Biophysics, Chinese Academy of Sciences). pMD.G was used to generate the stomatitis virus G (VSV-G) envelope [74]. $\mathrm{pCMV} \triangle \mathrm{R} 8.2$ is an encapsidation plasmid that contains the HIV-1 gag-pol gene, as well as some accessory protein genes [75]. pTRIP-GFP was derived from pHR'CMV LacZ, in which lacZ reporter gene was replaced by enhanced GFP (eGFP) [76]. pNL4-3-Luc contains a luciferase reporter, with the HIV-1 envelope gene sequence mutated [77]. MLV-Luc-producing plasmids pCMV-VSVG, pHIT60, and pMA-Luc have been previously described [17, 78].

$293 \mathrm{~T}$ cells were used to generate VSV-G pseudotyped HIV-1 or MLV. All retroviral vectors were pseudotyped with VSV-G to maintain one round of infection and produced by transient transfection into $293 \mathrm{~T}$ cells using Lipofectamine 2000 reagent (Invitrogen, Carlsbad, CA, USA). For HIV-1-GFP reporter virus (HIV-1-GFP) production, the proviral plasmid pTRIP-GFP, the encapsidation plasmid pCMVAR8.2, and the VSV-G envelope expression plasmid were used to cotransfect into $293 \mathrm{~T}$ cells at approximately $90 \%$ confluency, following the manufacturer's instructions. For HIV-1 luciferase reporter virus (HIV-1-Luc) production, the plasmid pNL4-3-Luc with the HIV-1 envelope gene sequences deleted, and the VSV-G envelope expression plasmid were used to cotransfect into $293 \mathrm{~T}$ cells as described above. To produce VSV-G pseudotyped MLV-Luc, pCMV-VSV-G, pHIT60, and pMA-Luc were transfected into $293 \mathrm{~T}$ cells. The supernatants containing the virus were harvested at 36,48 , 60 , and $72 \mathrm{~h}$ post transfection and treated with DNase I $(1 \mathrm{mg} / \mathrm{ml}$ in the presence of $10 \mathrm{mM} \mathrm{MgCl}$ ) for $60 \mathrm{~min}$ at $37^{\circ} \mathrm{C}$, followed by passage through a $0.45-\mu \mathrm{M}$ filter to remove cell debris. Virus stocks were stored at $-80{ }^{\circ} \mathrm{C}$. 10fold dilutions of the virus were used to infect $293 \mathrm{~T}$ cells.

\section{Single cycle infectivity assays and anti-HIV-1 activity of SJP-L-5}

293 T cells were seeded in dishes the day before infection. After $24 \mathrm{~h}$, the cells were incubated with recombinant viruses and $8 \mu \mathrm{g} / \mathrm{ml}$ polybrene, in the presence or absence of SJP-L- 5 at $37{ }^{\circ} \mathrm{C}$ in a $5 \% \mathrm{CO}_{2}$ atmosphere. The virus supernatant was removed and replaced with fresh medium $3 \mathrm{~h}$ post-viral infection, and SJP-L-5 was maintained at all times; SJP-L-5 was dissolved in DMSO. The final concentration of DMSO in the cell culture medium was kept at less than $0.3 \%$ to minimize the cytotoxicity of the solvent.

To test luciferase activities, the cells were washed once with cold PBS $48 \mathrm{~h}$ after infection and lysed in reporter lysis buffer (Promega, Madison, WI, USA) for $10 \mathrm{~min}$ on ice. The cell lysates were centrifuged at $12,000 \mathrm{~g}$ for $5 \mathrm{~min}$ at $4{ }^{\circ} \mathrm{C}$. Luciferase activity was determined by adding $100 \mu \mathrm{l}$ of substrate to $20 \mu \mathrm{l}$ of cell lysate using a luminometer (Promega, Model TD-20/20). The data presented are representative of three independent experiments.

\section{Hirt DNA extraction}

To quantify viral DNA products by real-time PCR, lowmolecular-weight DNA was extracted using the Hirt extraction method [79, 80]. Briefly, 293 T cells were washed with ice-cold PBS and lysed using lysis buffer (0.6 \% SDS, $10 \mathrm{mM}$ EDTA, $100 \mathrm{mM}$ Tris- $\mathrm{HCl}, \mathrm{pH}$ 7.5) at room temperature for $10 \mathrm{~min}$. Then $5 \mathrm{M} \mathrm{NaCl}$ was added and incubate at $4{ }^{\circ} \mathrm{C}$ overnight. The mixture was centrifuged at $4{ }^{\circ} \mathrm{C}$ for $30-60 \mathrm{~min}$. The DNA was extracted with phenol/chloroform/isoamyl alcohol (25:24:1) and precipitated by adding 2.5 volumes of ethanol. The DNA was resuspended in Tris-EDTA (TE) buffer and stored at $-20^{\circ} \mathrm{C}$.

\section{Real-time PCR}

Real-time PCR assays were performed using the SYBR Green Universal PCR Master Mix kit (TOYOBO, Tokyo, Japan), and the products were quantified using the deltadelta Ct method, which were performed using the Applied Biosystems ABI Prism 3000 sequence detection system (Thermo Fisher Scientific, Waltham, MA, USA).

All reactions were conducted in a total volume of $20 \mu \mathrm{l}$. To normalize the quantity of total cellular DNA present in each sample, human mitochondrial DNA was amplified and used as an internal control. Human mitochondria have a circular episomal DNA about $16.5 \mathrm{kbp}$ in length. A few hundred copies of mitochondrial DNA (mtDNA) are present in every cell. The primers used in this paper were as follows (Table 2) according to a previous report [81]: M-F and M-R were used for the amplification of -sssDNA. P-F and P-R were used for flDNA; CIR-F and CIR-R for Circular DNA; and Mito-F and Mito-R for human mitochondrial DNA. AZT was used as a positive control. The data presented are representative of three independent experiments.

\section{Transient transfections and subcellular localization studies} $1 \times 10^{5} 293 \mathrm{~T}$ cells were plated on coverslips in a 24-well plate. Transient transfection was performed using 
Table 2 Primers used to detect HIV-1 DNA products

\begin{tabular}{lll}
\hline Primer & Sequence & Position \\
\hline M-F & TtAGACCAGATCTGAGCCTGGGAG & R-U5 \\
M-R & GGGTCTGAGGGATCTCTAGTTACCAC & R-U5 \\
P-F & TGTGTGCCCGTCTGTTGTG & U5-gag \\
P-R & GAGTCCTGCGTCGAGA & U5-gag \\
CIR-F & CCCTCAGACCCTITAGTCAGTG & U5-U3 in 2-LTR circle \\
CIR-R & TGGTGTGTAGTTCTGCCAATCA & U5-U3 in 2-LTR circle \\
Mito-F & CCACTTCCACACAGACATC & \\
Mito-R & TCTGGTTAGGCTGGTGTAG & \\
\hline
\end{tabular}

Lipofectamine 2000 reagent (Invitrogen) when cells were approximately $90 \%$ confluent. $0.2 \mu \mathrm{g}$ of the abovementioned plasmids above was transfected according to the manufacturer's instructions. After $48 \mathrm{~h}$, the cells were fixed with $4 \%$ paraformaldehyde $(\mathrm{w} / \mathrm{v})$, and stained with 4 ', 6diamidina-2-phenylindole (DAPI) according to the manufacturer's protocol. The subcellular localization of the fusion proteins was analyzed by detecting GFP using a confocal microscope (PV1000-IX81, Olympus, Tokyo, Japan).

\section{Fate-of-capsid assay}

Approximately $6 \times 10^{6} 293 \mathrm{~T}$ cells were incubated with $4 \mathrm{ml}$ of undiluted recombinant viruses at $37{ }^{\circ} \mathrm{C}$. At each time point after infection, the cells were harvested for the sedimentation assay. Briefly, the cells were washed with ice-cold PBS and detached by pipetting up and down. Then, the cells were resuspended in $1.5 \mathrm{ml}$ of hypotonic lysis buffer (10 mM Tris- $\mathrm{HCl}, \mathrm{pH}$ 8.0, $10 \mathrm{mM} \mathrm{KCl,} 1 \mathrm{mM}$ EDTA, and one Complete Protease Inhibitor tablet (Roche, Basel, Switzerland)), and incubated on ice for $15 \mathrm{~min}$. The cells were lysed using 20 passes in a 2-ml Dounce homogenizer with pestle $\mathrm{B}$. The lysate was centrifuged at $800 \mathrm{~g}$ (KUBOTA, Tokyo, Japan) for $5 \mathrm{~min}$ to remove cell debris. After centrifugation, $100 \mu \mathrm{l}$ of the cleared lysate was collected and mixed with $2 \times$ sodium dodecyl sulfate (SDS) sample buffer, which was referred to as the p24 input fraction. $1 \mathrm{ml}$ of the cleared lysate was layered onto a $50 \%$ sucrose $(\mathrm{w} / \mathrm{v})$ cushion in PBS and centrifuged at $125,000 \mathrm{~g}$ for $2 \mathrm{~h}$ at $4{ }^{\circ} \mathrm{C}$ in a P40ST rotor (Hitachi, Tokyo, Japan). After centrifugation, $100 \mu \mathrm{l}$ of the uppermost part of the supernatant was collected and mixed with $2 \times$ SDS sample buffer; this part was referred to as the p24 soluble fraction. The pellet was resuspended in $50 \mu \mathrm{l}$ of $1 \times$ SDS sample buffer and referred to as the $\mathrm{p} 24$ particulate fraction; $\beta$-Actin was used as a pellet fraction control. All samples were then subjected to SDS-PAGE and Western blotting. The HIV-1 p24 CA protein was detected using a mouse monoclonal antibody purified by the laboratory of Professor Yongtang Zheng. The data presented are representative of three independent experiments.

\section{Transmission electron microscopy}

$293 \mathrm{~T}$ cells were seeded in dishes the day before infection. After $24 \mathrm{~h}$, the cells were incubated with VSV-G pseudotyped HIV-1 and polybrene at a final concentration of $8 \mu \mathrm{g} / \mathrm{ml}$ in the presence or absence of SJP-L-5 at $37{ }^{\circ} \mathrm{C}$. The virus supernatant was removed and replaced with fresh medium $4 \mathrm{~h}$ post-viral infection, and SJP-L-5 was maintained at all times. At $4 \mathrm{~h}$ and $8 \mathrm{~h}$ post infection, the cells were harvested for the TEM assay. Cells were fixed for $12 \mathrm{~h}$ at $4{ }^{\circ} \mathrm{C}$ in $2.5 \%$ glutaraldehyde in $0.1 \mathrm{M}$ phosphate buffer ( $\mathrm{pH} 7.3)$, washed, fixed again in aqueous $1 \%$ osmium tetroxide, and embedded in EPON. TEM was performed with a Tecnai G2 Spirit-120 kV transmission electron microscope (FEI, Hillsboro, OR, USA), at $120 \mathrm{kV}$, on ultrathin sections (80-nm thick) stained with uranyl acetate and lead citrate. 20 cells per field were selected randomly in the control and SJP-L-5 groups. Quantification of total HIV-1 was performed on 20 fields in the control and SJP-L-5 groups.

\section{Statistical analysis}

Results were presented as mean \pm S.D. of three independent experiments. The differences between control and target data sets was tested by Student's $t$ test, and P-values $\leq$ 0.05 were considered to be of statistical significance.

\section{Additional files}

\begin{abstract}
Additional file 1: Primers used in plasmid constructions. Table S1. Primers used in plasmid constructions. (DOCX $18 \mathrm{~kb}$ )

Additional file 2: Subcellular localization of HIV-1 IN, MA, and Vpr in transfected cells. Figure S1. Subcellular distributions of HIV-1 IN, MA and Vpr in transfected cells. (A). Subcellular distributions of HIV-1 IN, MA, and Vpr in control cells. 293 T cells were transiently transfected with $0.2 \mu \mathrm{g}$ of the plasmids pC1-GFP, pC1-GFP ${ }_{2}-\mathrm{NLS}$, pGFP-IN, pGFP-MA, or pGFP-Vpr using Lipofectamine 2000 reagent, the primers used in plasmid constructions were shown in Additional file 1: Table S1. At 48 h post transfection, the cells were fixed with $4 \%$ paraformaldehyde $(\mathrm{W} / \mathrm{v})$ and then stained with DAPI. (B-D). Subcellular distributions of HIV-1 IN, MA, and Vpr in SJP-L-5 treated cells. 293 T cells were transiently transfected with $0.2 \mu \mathrm{g}$ of the plasmids pGFP-IN (B), pGFP-MA (C), or pGFP-Vpr (D) using Lipofectamine 2000 reagent in the presence of $5 \mu \mathrm{g} / \mathrm{ml}$ or $20 \mu \mathrm{g} /$ $\mathrm{ml}$ of SJP-L-5. At $48 \mathrm{~h}$ post transfection, the cells were fixed with $4 \%$ paraformaldehyde (w/v) and then stained with DAPI. GFP (Green) and DAPI (Blue) fluorescence were observed using a confocal microscope. (TIFF 1744 kb)
\end{abstract}

Additional file 3: The effect of SJP-L-5 on the HIV-1 DNA flap. Figure S2. The effect of SJP-L-5 on the HIV-1 DNA flap. 293 T cells were infected with VSV-G pseudotyped NL4-3-Luc or CMVAR8.2-Luc in the presence of SJP-L-5 (5 $\mathrm{\mu g} / \mathrm{ml}$, Gray) or DMSO (Black) as a negative control. The antiretroviral activity was evaluated by testing the activity of the luciferase reporter gene at $48 \mathrm{~h}$ post infection. Error bars indicate standard deviations of triplicate values. Statistical significance was analyzed by the Student's $t$ test. ${ }^{* * *} P<0.001$ versus the negative control. (TIFF 370 kb)

\section{Abbreviations}

HIV-1: Human immunodeficiency virus, type1; MLV: Murine leukemia virus; PIC: Pre-integration complex; NPC: Nuclear pore complexes; CA, MA, IN, Vpr: The capsid, matrix, integrase, and viral protein regulatory of HIV-1, respectively; PBMC: Peripheral blood mononuclear cell; NLS: Nuclear localization signal; sssDNA: single strand strong-stop DNA; LTR: Long terminal 
repeat; TEM: Transmission electron microscopy; MOI: Multiplicity of infection; $\mathrm{CC}_{50}: 50 \%$ cytotoxicity concentration; $\mathrm{EC}_{50}: 50 \%$ effective concentration.

\section{Competing interests}

All authors declare no competing interests.

\section{Authors' contributions}

$L X L$ and YTZ conceived and designed the study. RB performed the experiments and analyzed the data. XJZ carried out the experiments of cytotoxicity and antiviral activity of SJP-L-5. LXL, RB and YLL wrote the paper. JPL and HBZ designed and synthesized the compound SJP-L-5. WLX and HDS designed compound SJP-L-5 and participated the discussion of the results. JXP participated the design of S.JP-L-5. All authors have read and approved the final version of the manuscript.

\section{Acknowledgements}

This work was supported in part by grants from the 973 Program (2009CB522306), the Eleventh Five-Year Key Scientific and Technological Program of China (2009ZX09501-029, 2009ZX09103-414,2012ZX10001-006, 2012ZX10001-007) and Yunnan Provinces (2015FB182), the Major Drug Discovery Project of the National Twelfth-Five Year Research Program of China (2013ZX09103001-010), and the CAS Knowledge Innovation Project (KFJ-EW-STS-026).

\section{Author details 100049, P. R. China. ${ }^{2}$ Sun Yat-Sen University, Guangzhou 510275, P. R. China. ${ }^{3}$ Key Laboratory of Animal Models and Human Disease Mechanisms of the Chinese Academy of Sciences and the Kunming Institute of Zoology of the Chinese Academy of Sciences, Kunming 650223, P. R. China. ${ }^{4}$ State Key Laboratory of Phytochemistry and Plant Resources in West China, Kunming Institute of Botany, Chinese Academy of Sciences, Kunming 650204, P. R. of Education, School of Chemical Science and Technology, Yunnan University, Kunming 650091, P. R. China. \\ Received: 19 January 2015 Accepted: 24 November 2015 Published online: 02 December 2015}

${ }^{1}$ College of Life Sciences, University of Chinese Academy of Sciences, Beijing China. ${ }^{5}$ Key Laboratory of Medicinal Chemistry for Natural Resources, Ministry

\section{References}

1. Arts EJ, Hazuda DJ. HIV-1 antiretroviral drug therapy. Cold Spring Harb Perspect Med. 2012;2:4.

2. Hogg RS, Yip B, Kully C, Craib K, O'Shaughnessy MV, Schechter MT, et al. Improved survival among HIV-infected patients after initiation of triple-drug antiretroviral regimens. CMAJ. 1999;160(5):659-65.

3. Volberding PA, Deeks SG. Antiretroviral therapy and management of HIV infection. Lancet. 2010;376(9734):49-62.

4. Timmins P, Brown J, Meanwell NA, Hanna GJ, Zhu L, Kadow JF. Enabled clinical use of an HIV-1 attachment inhibitor through drug delivery. Drug Discov Today. 2014;19(9):1288-93.

5. Kohlstaedt LA, Wang J, Friedman JM, Rice PA, Steitz TA. Crystal-structure at 3.5 angstrom resolution of HIV-1 reverse-transcriptase complexed with an inhibitor. Science. 1992;26(5065):1783-90.

6. Morningstar ML, Roth T, Farnsworth DW, Smith MK, Watson K, Buckheit RW, et al. Synthesis, biological activity, and crystal structure of potent nonnucleoside inhibitors of HIV-1 reverse transcriptase that retain activity against mutant forms of the enzyme. J Med Chem. 2007;50(17):4003-15.

7. Ehteshami M, Scarth BJ, Tchesnokov EP, Dash C, Le Grice SFJ, Hallenberger $\mathrm{S}$, et al. Mutations M184V and Y115F in HIV-1 reverse transcriptase discriminate against "Nucleotide-competing reverse transcriptase inhibitors". J Biol Chem. 2008;283(44):29904-11.

8. Jochmans D, Deval J, Kesteleyn B, Van Marck H, Bettens E, De Baere I, et al. Indolopyridones inhibit human immunodeficiency virus reverse transcriptase with a novel mechanism of action. J Virol. 2006;80(24):12283-92.

9. Matreyek KA, Engelman A. Viral and cellular requirments for the nuclear entry of retroviral preintegration nucleoprotein complexes. Viruese. 2013; 5(10):2483-511.

10. Haffar OK, Popov S, Dubrovsky L, Agostini I, Tang H, Pushkarsky T, et al. Two nuclear localization signals in the HIV-1 matrix protein regulate nuclear import of the HIV-1 pre-integration complex. J Mol Biol. 2000;299(2):359-68.
11. Bouyac-Bertoia M, Dvorin JD, Fouchier RAM, Jenkins $Y$, Meyer BE, Wu LI, et al. HIV-1 infection requires a functional integrase NLS. Mol Cell. 2001;7(5): 1025-35.

12. Jenkins $Y$, McEntee $M$, Weis $K$, Greene WC. Characterization of HIV-1 Vpr nuclear import: Analysis of signals and pathways. J Cell Biol. 1998;143(4):875-85.

13. De Rijck J, Debyser Z. The central DNA flap of the human immunodeficiency virus type 1 is important for viral replication. Biochem Bioph Res Co. 2006:349(3):1100-10.

14. Fassati A. Multiple roles of the capsid protein in the early steps of HIV-1 infection. Virus Res. 2012;170(1-2):15-24.

15. Hulme AE, Kelley Z, Foley D, Hope TJ. Complementary assays reveal a low level of CA associated with nuclear HIV-1 viral complexes. J Virol. 2015; 89(10):5350-61.

16. Liu JP, Sun HD, Zhang HB, Zheng YT, Xiao WL, Pu JX, et al. Procedures towards the synthesis of a class of nitrogen-containing biphenyl derivatives and application in the area of anti-HIV-1 activities. In: China Patent. China. 2010.

17. Gao GX, Guo XM, Goff SP. Inhibition of retroviral RNA production by ZAP, a CCCH-type zinc finger protein. Science. 2002;297(5587):1703-6.

18. Jonckheere H, Anne J, De Clercq E. The HIV-1 reverse transcription (RT) process as target for RT inhibitors. Med Res Rev. 2000;20(2):129-54.

19. Goff SP. Retroviridae: the retroviruses and their replication. In: Knipe DM, Howley PM, editors. Fields virology. Philadelphia: Lippincott Williams \& Wilkins; 2001. p. 1871-939.

20. Bukrinsky MI, Sharova N, Dempsey MP, Stanwick TL, Bukrinskaya AG, Haggerty $S$, et al. Active nuclear import of human immunodeficiency virus type 1 preintegration complexes. Proc Natl Acad Sci U S A. 1992;89(14):6580-4.

21. Anderson JL, Hope TJ. APOBEC3G restricts early HIV-1 replication in the cytoplasm of target cells. Virology. 2008;375(1):1-12.

22. Stremlau M, Perron M, Lee M, Li Y, Song B, Javanbakht H, et al. Specific recognition and accelerated uncoating of retroviral capsids by the TRIM5alpha restriction factor. Proc Natl Acad Sci U S A. 2006;103(14):5514-9.

23. Levin A, Armon-Omer A, Rosenbluh J, Melamed-Book N, Graessmann A,

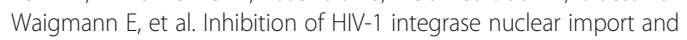
replication by a peptide bearing integrase putative nuclear localization signal. Retrovirology. 2009;6:112.

24. Armon-Omer A, Graessmann A, Loyter A. A synthetic peptide bearing the HIV-1 integrase 161-173 amino acid residues mediates active nuclear import and binding to importin alpha: characterization of a functional nuclear localization signal. J Mol Biol. 2004;336(5):1117-28.

25. Mousnier A, Leh H, Mouscadet JF, Dargemont C. Nuclear import of HIV-1 integrase is inhibited in vitro by styrylquinoline derivatives. Mol Pharmacol. 2004;66(4):783-8.

26. Bukrinsky MI, Haggerty S, Dempsey MP, Sharova N, Adzhubel A, Spitz L, et al. A nuclear localization signal within HIV-1 matrix protein that governs infection of non-dividing cells. Nature. 1993;365(6447):666-9.

27. von Schwedler U, Kornbluth RS, Trono D. The nuclear localization signal of the matrix protein of human immunodeficiency virus type 1 allows the establishment of infection in macrophages and quiescent T lymphocytes. Proc Natl Acad Sci U S A. 1994;91(15):6992-6.

28. Gallay P, Swingler S, Aiken C, Trono D. HIV-1 infection of nondividing cells: C-terminal tyrosine phosphorylation of the viral matrix protein is a key regulator. Cell. 1995;80(3):379-88.

29. Al-Abed Y, Dubrovsky L, Ruzsicska B, Seepersaud M, Bukrinsky M. Inhibition of HIV-1 nuclear import via Schiff base formation with arylene bis(methylketone) compounds. Bioorg Med Chem Lett. 2002;12(21):3117-9.

30. Mannioui A, Nelson E, Schiffer C, Felix N, Le Rouzic E, Benichou S, et al. Human immunodeficiency virus type 1 KK26-27 matrix mutants display impaired infectivity, circularization and integration but not nuclear import. Virology. 2005;339(1):21-30.

31. Levin R, Mhashilkar AM, Dorfman T, Bukovsky A, Zani G, Bagley J, et al. Inhibition of early and late events of the HIV-1 replication cycle by cytoplasmic fab intrabodies against the matrix protein, p17. Mol Med. 1997; 3(2):96-110.

32. Heinzinger NK, Bukrinsky MI, Haggerty SA, Ragland AM, Kewalramani V, Lee MA, et al. The Vpr Protein of human-immunodeficiency-virus type-1 influences nuclear-localization of viral nucleic-acids in nondividing host-cells. Proc Natl Acad Sci U S A. 1994;91(15):7311-5.

33. Anderson $J$ L, Hope TJ. Intracellular trafficking of retroviral vectors: obstacles and advances. Gene Ther. 2005;12(23):1667-1678.

34. Yamashita M, Emerman M. Retroviral infection of non-dividing cells: Old and new perspectives. Virology. 2006;344(1):88-93. 
35. Yamashita M, Emerman M. The cell cycle independence of HIV infections is not determined by known karyophilic viral elements. PLoS Pathog. 2005;1(3), e18.

36. Yamashita M, Emerman M. Capsid is a dominant determinant of retrovirus infectivity in nondividing cells. J Virol. 2004;78(11):5670-8.

37. Yamashita M, Perez O, Hope TJ, Emerman M. Evidence for direct involvement of the capsid protein in HIV infection of nondividing cells. PLoS Pathog. 2007;3(10):1502-10.

38. Perron MJ, Stremlau M, Lee M, Javanbakht H, Song B, Sodroski J. The human TRIM5alpha restriction factor mediates accelerated uncoating of the N-tropic murine leukemia virus capsid. J Virol. 2007:81(5):2138-48.

39. Diaz-Griffero F, Perron M, McGee-Estrada K, Hanna R, Maillard PV, Trono D, et al. A human TRIM5alpha B30.2/SPRY domain mutant gains the ability to restrict and prematurely uncoat B-tropic murine leukemia virus. Virology. 2008:378(2):233-42.

40. Bowerman B, Brown PO, Bishop JM, Varmus HE. A nucleoprotein complex mediates the integration of retroviral DNA. Gene Dev. 1989;3(4):469-78.

41. Fassati A, Goff SP. Characterization of intracellular reverse transcription complexes of Moloney murine leukemia virus. J Virol. 1999;73(11):8919-25.

42. Bukrinsky MI, Sharova N, Mcdonald TL, Pushkarskaya T, Tarpley WG, Stevenson M. Association of integrase, matrix, and reverse-transcriptase antigens of human-immunodeficiency-virus type-1 with viral nucleicacids following acute infection. Proc Natl Acad Sci U S A. 1993;90(13): 6125-9.

43. Farnet $\mathrm{CM}$, Haseltine WA. Determination of viral-proteins present in the human-immunodeficiency-virus type-1 preintegration complex. J Virol. 1991; 65(4):1910-5.

44. Fassati A, Goff SP. Characterization of intracellular reverse transcription complexes of human immunodeficiency virus type 1. J Virol. 2001;75(8): 3626-35.

45. Karageorgos L, Li P, Burrell C. Characterization of HIV replication complexes early after cell-to-cell infection. Aids Res Hum Retrov. 1993;9(9):817-23.

46. Lamorte L, Titolo S, Lemke CT, Goudreau N, Mercier JF, Wardrop E, et al. Discovery of novel small-molecule HIV-1 replication inhibitors that stabilize capsid complexes. Antimicrob Agents Ch. 2013;57(10):4622-31.

47. Shi J, Zhou J, Shah VB, Aiken C, Whitby K. Small-molecule inhibition of human immunodeficiency virus type 1 infection by virus capsid destabilization. J Virol. 2011;85(1):542-9.

48. Fricke $T$, White $T E$, Schulte $B$, de Souza Aranha Vieira DA, Dharan A, Campbell EM, et al. MxB binds to the HIV-1 core and prevents the uncoating process of HIV-1. Retrovirology. 2014;11:68.

49. Fricke T, Valle-Casuso JC, White TE, Brandariz-Nunez A, Bosche WJ, Reszka N, et al. The ability of TNPO3-depleted cells to inhibit HIV-1 infection requires CPSF6. Retrovirology. 2013;10:46.

50. Price AJ, Fletcher AJ, Schaller T, Elliott T, Lee K, KewalRamani VN, et al. CPSF6 defines a conserved capsid interface that modulates HIV-1 replication. PLoS Pathog. 2012;8:8

51. Fricke T, Buffone C, Opp S, Valle-Casuso J, Diaz-Griffero F. Bl-2 destabilizes HIV-1 cores during infection and Prevents Binding of CPSF6 to the HIV-1 Capsid. Retrovirology. 2014;11(1):120.

52. Stremlau M, Owens CM, Perron MJ, Kiessling M, Autissier P, Sodroski J. The cytoplasmic body component TRIM5alpha restricts HIV-1 infection in Old world monkeys. Nature. 2004;427(6977):848-53.

53. Yap MW, Dodding MP, Stoye JP. Trim-cyclophilin a fusion proteins can restrict human immunodeficiency virus type 1 infection at two distinct phases in the viral life cycle. J Virol. 2006;80(8):4061-7.

54. Yamashita M, Emerman M. Cellular restriction targeting viral capsids perturbs human immunodeficiency virus type 1 infection of nondividing cells. J Virol. 2009:83(19):9835-43.

55. Lin TY, Emerman M. Determinants of cyclophilin A-dependent TRIM5 alpha restriction against HIV-1. Virology. 2008;379(2):335-41.

56. Anderson JL, Campbell EM, Wu XL, Vandegraaff N, Engelman A, Hope TJ. Proteasome inhibition reveals that a functional preintegration complex intermediate can be generated during restriction by diverse TRIM5 proteins. J Virol. 2006;80(19):9754-60

57. Wu X, Anderson JL, Campbell EM, Joseph AM, Hope TJ. Proteasome inhibitors uncouple rhesus TRIM5alpha restriction of HIV-1 reverse transcription and infection. Proc Natl Acad Sci U S A. 2006;103(19):7465-70.

58. Kim J, Tipper C, Sodroski J. Role of TRIM5alpha RING domain E3 ubiquitin ligase activity in capsid disassembly, reverse transcription blockade, and restriction of simian immunodeficiency virus. J Virol. 2011;85(16):8116-32.
59. Danielson CM, Cianci GC, Hope TJ. Recruitment and dynamics of proteasome association with rhTRIM5alpha cytoplasmic complexes during HIV-1 infection. Traffic. 2012;13(9):1206-17.

60. Kutluay SB, Perez-Caballero D, Bieniasz PD. Fates of retroviral core components during unrestricted and TRIM5-restricted infection. PLoS Pathog. 2013;9(3), e1003214.

61. Campbell EM, Perez O, Anderson JL, Hope TJ. Visualization of a proteasomeindependent intermediate during restriction of HIV-1 by rhesus TRIM5alpha. J Cell Biol. 2008;180(3):549-61.

62. Lee K, Ambrose Z, Martin TD, Oztop I, Mulky A, Julias JG, et al. Flexible use of nuclear import pathways by HIV-1. Cell Host Microbe. 2010;7(3): 221-33.

63. Hori T, Takeuchi H, Saito H, Sakuma R, Inagaki Y, Yamaoka S. A carboxy-terminally truncated human CPSF6 lacking residues encoded by exon 6 inhibits HIV-1 CDNA synthesis and promotes capsid disassembly. J Virol. 2013;87(13):7726-36.

64. Di Nunzio F, Danckaert A, Fricke T, Perez P, Fernandez J, Perret E, et al. Human nucleoporins promote HIV-1 docking at the nuclear pore, nuclear import and integration. PLoS One. 2012;7(9), e46037.

65. Lin DH, Zimmermann S, Stuwe T, Stuwe E, Hoelz A. Structural and functional analysis of the C-terminal domain of Nup358/RanBP2. J Mol Biol. 2013:425(8):1318-29

66. Di Nunzio F, Fricke T, Miccio A, Valle-Casuso JC, Perez $P$, Souque $P$, et al. Nup153 and Nup98 bind the HIV-1 core and contribute to the early steps of HIV-1 replication. Virology. 2013:440(1):8-18.

67. De laco A, Luban J. Cyclophilin a promotes HIV-1 reverse transcription but its effect on transduction correlates best with its effect on nuclear entry of viral cDNA. Retrovirology. 2014;11:11.

68. Gross I, Hohenberg H, Huckhagel C, Krausslich HG. N-terminal extension of human immunodeficiency virus capsid protein converts the in vitro assembly phenotype from tubular to spherical particles. J Virol. 1998;72(6): 4798-810.

69. Turner BG, Summers MF. Structural biology of HIV. J Mol Biol. 1999;285(1):1-32.

70. Matreyek KA, Engelman A. The requirement for nucleoporin NUP153 during human immunodeficiency virus type 1 infection is determined by the viral capsid. J Virol. 2011;85(15):7818-27.

71. Pannecouque C, Daelemans D, De Clercq E. Tetrazolium-based colorimetric assay for the detection of HIV replication inhibitors: revisited 20 years later. Nat Protoc. 2008;3(3):427-34.

72. Zhang XJ, Lu LH, Wang RR, Wang YP, Luo RH, Lai CC, et al. DB-02, a C-6-Cyclohexylmethyl substituted pyrimidinone HIV-1 reverse transcriptase inhibitor with nanomolar activity, displays an improved sensitivity against K103N or Y181C than S-DABOs. PLoS One. 2013:8(11), e81489.

73. Wang RR, Yang LM, Wang YH, Pang W, Tam SC, Tien P, et al. Sifuvirtide, a potent HIV fusion inhibitor peptide. Biochem Bioph Res Co. 2009;382(3): 540-4.

74. Ory DS, Neugeboren BA, Mulligan RC. A stable human-derived packaging cell line for production of high titer retrovirus/vesicular stomatitis virus $G$ pseudotypes. Proc Natl Acad Sci U S A. 1996;93(21):11400-6.

75. Naldini L, Blomer U, Gage FH, Trono D, Verma IM. Efficient transfer, integration, and sustained long-term expression of the transgene in adult rat brains injected with a lentiviral vector. Proc Natl Acad Sci U S A. 1996; 93(21):11382-8.

76. Zennou V, Petit C, Guetard D, Nerhbass U, Montagnier L, Charneau P. HIV-1 genome nuclear import is mediated by a central DNA flap. Cell. 2000;101(2): 173-85.

77. Akkina RK, Walton RM, Chen ML, Li QX, Planelles V, Chen ISY. High-efficiency gene transfer into CD34(+) cells with a human immunodeficiency virus type 1 -based retroviral vector pseudotyped with vesicular stomatitis virus envelope glycoprotein G. J Virol. 1996;70(4):2581-5.

78. Guo XM, Carroll JWN, MacDonald MR, Goff SP, Gao GX. The zinc finger antiviral protein directly binds to specific viral mRNAs through the $\mathrm{CCCH}$ zinc finger motifs. J Virol. 2004;78(23):12781-7.

79. Ziegler K, Bui T, Frisque RJ, Grandinetti A, Nerurkar VR. A rapid in vitro polyomavirus DNA replication assay. J Virol Methods. 2004;122(1):123-7.

80. Tang YY, Villinger F, Staprans SI, Amara RR, Smith JM, Herndon JG, et al Slowly declining levels of viral RNA and DNA in DNA/recombinant modified vaccinia virus Ankara-vaccinated macaques with controlled simian-human immunodeficiency virus SHIV-89.6P challenges. J Virol. 2002;76(20):10147-54.

81. Liu Z, Pan Q, Ding S, Qian J, Xu F, Zhou J, et al. The interferon-inducible MxB protein inhibits HIV-1 infection. Cell Host Microbe. 2013;14(4):398-410. 